\title{
International Practice of Innovation Infrastructure Creation as a Mechanism for the Innovative Economy Development and the Improvement of Land Use Effectiveness
}

\author{
Ekaterina S. Murzina* \\ National Research University Higher School of Economics \\ 20 Myasnitskaya Str., Moscow, 101000, Russia
}

Received 03.09.2015, received in revised form 30.09.2015, accepted 20.10.2015

The paper was prepared by a postgraduate student of the 3rd year of study of the National Research University - Higher School of Economics within the conceptual framework of her current PhD dissertation project. The article reports original research results and examines the issues of the concept of formation and activity of science and technology parks as some of the key objects of innovation infrastructure. Through the analysis of the world practice of industrial and university areas' redevelopment, the main models of technopark structures' formation have been identified as well as basic forms and characteristics of modern science and technology parks and the conditions for their effective functioning. The author also highlights the necessity to consider international best practice of technopark development while implementing the Russian strategy of functional conversion of redundant inner city industrial areas.

Keywords: : innovation infrastructure, science and technology parks (STP), redevelopment of industrial zones, models of technoparks creation, science-based production, STP located entity, technoparks specialization.

DOI: 10.17516/1997-1370-2015-8-11-2535-2544.

Research area: economics.

\section{Introduction}

Redevelopment of the industrial areas is relevant to many modern urban economies. With urgent need to enhance efficiency of urban areas use by searching for the new economic growth sources, one of the economically feasible urban solutions is the application of innovation models of development of the industrial areas (Goldstein, 1990).

Moreover, the need to restructure the Russian economy using import substitution makes the reshaping of the industrial urban areas one of the most promising directions in the modern industry development and creation of the innovative, knowledge-intensive and high-tech production facilities. The state priorities in development of the industrial areas shift towards the creation of a specialized innovative infrastructure within the spaces in question (Collaton, 1996).

Such reshaping of the industrial areas results from their redundant inner city presence and the need to develop modern, knowledge-intensive,

(C) Siberian Federal University. All rights reserved

* Corresponding author E-mail address: e_murzina@mail.ru 
innovative production facilities. Nowadays, for example, over $10 \%$ of the territory of major Russian cities is occupied with industrial facilities, while the maximum share of industrial areas in the total area of a foreign megapolis is about $3 \%-5 \%$ (Korolenko, 2011).

The advanced foreign practice of the industrial areas redevelopment proves that the creation of the innovative infrastructure facilities in the former industrial areas is an efficient way of redeployment and city reshaping, because technology parks, technopolises, business incubators and other innovation infrastructure facilities are one of the crucial tools of shaping the innovation-based economy (Murzina, 2014).

\section{Key Models of Creation of the Innovative Infrastructure Facilities Abroad}

Creation of innovative infrastructure facilities in the excessive and misused areas of various establishments dates back to the 1950's. Thus, the first object of innovative infrastructure emerged in the world practice in 1951 in the United States (California), when the Stanford research (science) park was created (after the English 'Silicon Valley') (Doutriaux, 1998). The University management resolved it would be feasible to lease out the premises not used in its core activities to small businesses operating in the high-tech area. The business of the park located entities (in the modern sense, the technology park residents) in the innovative areas made a good progress thanks to the federal government's defense orders, the research teamwork with the University and the territorial proximity of technology companies to each other. Venture capital financing, a special pattern of financing high-tech innovative projects, first invented and introduced in the Stanford technological cluster, also contributed to its economic success.
Thus, since its inception, the Stanford technology park has transformed into a hightech cluster that has not only laid the groundwork for shaping similar areas in many countries by promoting the science-intensive sector of industry, but also contributed to converting the area of its operation (California) into a global center for research, technology, finance and education (McAndrews, 1995).

However, more active shaping of innovative infrastructure facilities - science and research parks and technopolises - worldwide goes back to 1960s, when development of the new, high technologies to provide the science and technology progress and the accelerated industrial development became one of the top state priorities in such countries as the United States, Japan and the USSR.

USSR and Japan were actively involved in the creation of the innovative infrastructure facilities for development of the ground-breaking industries from the late 1950's to the early 1960's: the Siberian Academic Town (or science campus) established in 1957 was the first technopolis ever in the world, and in 1965, the Japanese 'Silicon Valley' named 'Silicon Kyushu Island', was founded (Kostyunina, 2012).

In the second half of the 1960's - early 1970's, technopolises, research, science and technology parks mushroomed in Europe. Among the first were the Research Park of University of SOPHIAANTIPOLIS (Nice) and the area of scientific and technical innovations and production (ZIRST) (Grenoble) in France; the technology park of Cologne in Germany; the science park LEUVENLA-NEUVE in Belgium; 'Silicon Fen' in Cambridge (Cambridge Cluster) and Heriot-Watt in Edinburgh (the United Kingdom); the Finnish 'Silicon Valley' in Helsinki.

For example, the first technology parks in France and Belgium were quite big organizations attracting to its territory the well-established 
companies in various industry-specific areas. These organizations did not prioritize the formation and support of the small high-tech firms starting their innovative activities, as well as the technology transfer from science to industry in the early years of the French and Belgian technological clusters.

However, after the initial period of the formation of technology parks, in 1972, one of the most famous and successful project in creation of the innovative infrastructure facilities not only in France, but all over the world SOPHIA-ANTIPOLIS Technology Park - was implemented. It specializes not only in attracting the innovation enterprises and new investment, but also in setting up the new high-tech companies and highly-qualified workstations. The today's 2,300 ha technological cluster accommodates 1,400 innovative firms, national and international organizations, research and innovation centers, higher educational institutions, residential districts, recreation areas and sports facilities (Sophia Antipolis, 2015).

In Germany, technological and science parks (as well as innovation centers) rapid growth began in the 1980's. In 1983, they created the first example of innovative infrastructure facilities, the Berlin Innovation Center (BIC), as a tool of unemployment reduction among Berlin graduates, scientists and engineers (Economic and Social Commission for Asia and the Pacific, 2001).

In the context of prospects of similar projects implementing in Russia, the German experience in creation and operation of the technology park of Cologne, created in the territory of an outmoded chemical plant (of the total area of about 141,000 sq.m. and the production one - about 50,000 sq.m.), is especially interesting (TechnologiePark Koln, 2015).

In the early 1980 's, the plant was sold to a private investor, reconstructed and set in operation as a technology park leasing out its premises to the small and medium-size high-tech companies. To enhance operating efficiency of the firms already existing in the territory of the park and to attract new resident companies, a technology center was established within the territory of the created object of innovation infrastructure, intended to provide free professional consulting services on business organization and doing business (on making the companies' business plans, etc.).

By the late 1980's, Germany was wellpositioned to establish an organization consolidating the innovative infrastructure objects in search for best operating practices for technology, science and industrial parks or clusters. That is why the German Association of Innovation, Technology and Business Incubation Centres (ADT) was created in 1988 to facilitate the experience exchange between the designated partnership organizations in Germany, as well as with the foreign innovation centers of technologies (Economic and Social Commission for Asia and the Pacific, 2001).

Not without interest is the British practice of the innovative infrastructure creation. The Cambridge Science Park (technology park) established by Trinity College in 1975 is among the most famous technology parks based in a university (Liu, 2006).

Such project was necessitated by the objective set at the highest national level - to strengthen relations between the UK universities and the knowledge-intensive industry in the late 1960's. The authority, outstanding scholarly traditions and a significant territory of Trinity College determined the choice of the site for a future technological cluster.

The science park was developed both by expanding the existing companies and by attracting new ones. At present, over 80 hightech companies carry out their business in the Cambridge Technopark in such areas as biotechnologies, energy industry, software, 
industrial technologies, electronics, computer technologies, telecommunications, etc. The total area of the park premises is 93,000 sq.m., where nearly 50,000 sq.m. is the research and testing labs (in the future the plan is to extend it to 140,000 sq.m.) (Liu, 2006). The unique park's feature is a non-typical ratio of the built-up and vacant areas of the park territory, which is 1:6, while in a significant portion of similar facilities the aforesaid ratio is $1: 2$.

According to the general world practice, the use of the Cambridge Science Park facilities is only allowed for the applied research and light industrial manufacturing (subject to the regular consultations with the University's academicians or representatives of other scientific institution of the region); as well as for carrying out of a corresponding supporting activity.

The practice of functioning of the HeriotWatt Research Park - one of the most important scientific centers in Scotland established at Heriot-Watt University in Edinburgh in 1966 - is also interesting. This innovation special-purpose infrastructure facility is the only science cluster in Europe where research is only allowed and mass production is prohibited.

The above special-purpose innovation infrastructure facilities in Europe were shaped by the model of establishment of the first technological parks in the United States, the key feature of which is the availability of one founder and the core business - the lease-out of premises to the knowledge-intensive companies' owners. However, for the technology parks of Europe, created in the 1960 's/ 1980 's, a shorter establishment and development period is typical.

Based on the global experience in creation of the innovative infrastructure facilities, the following 3 models of their functioning can be distinguished: American (the U.S. and the U.K.); Japanese (Japan) and mixed (France, Germany, etc.).
The American model is described by the existence of mostly science and research parks, where universities lease out their premises to the small high-tech companies at reasonable prices, providing them with the access to the required lab equipment ('cleanrooms' etc.) and services. The main objective of such parks is to support not only the establishment but also the development stage of small innovative firms, by the means of attracting investors and financing from the social and proprietary funds.

The Japanese model of innovative infrastructure creation, unlike the American one, presupposes, first of all, the setup of the entirely new cities - 'Technopolises' that concentrate scientific research in the high-tech pioneering industries and knowledge-intensive production.

The example of the mixed model, featuring both the American and Japanese model attributes, can be European science parks, especially French ones ('Sophia-Antipolis', etc.). The modern European science or technology park model has the following features (Barinova et al., 2012):

- Sufficient premises intended for the positioning of resident companies in them;

- Several founders which assumes more complicated management mechanism than in a case with a sole founder, however, much more efficient, especially, in terms of access to funding. Normally, the founders of such type of parks include a university or a research center/ institute providing scientific support to the park; the regional authorities granting land for use and providing the required infrastructure; and also an area development agency or an organization providing grants or any other support required.

Thus, the data of the 2015 statistical analysis conducted by the International Association of Science Parks (IASP) suggests that $29.4 \%$ of world science and technology parks are jointly owned by government and private institutions, 


\section{STP ownership}

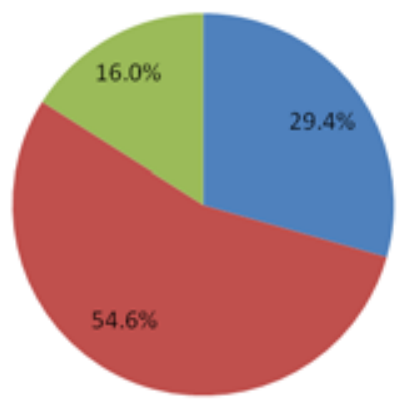

Fig. 1: Science and Technology Parks Ownership
As concerns the terminological details among the similar facilities of the innovative infrastructure entities, inference should be drawn that science parks prevail in the U.K., innovative centers in Germany, research parks in the U.S., science and industrial parks or high-tech areas in China. However, technology parks prevail worldwide as the collective and most popular name of the innovative infrastructure facilities. Thus, such term as 'technopark' may include various types of high-tech infrastructure science parks, university and research clusters, innovation centers, scientific research parks, etc. The differences between the above-mentioned innovation infrastructure facilities are minor and relate to the type and size of resident companies, the specific nature of the facility management (one management company or group of persons; full, partial or missing ownership by university), the number of technologies supported (one or many), the facility's activity nature (commercial or noncommercial) and other factors. In some sources, such concept as 'technology park' also includes 'technopolis', if it contains sufficient areas for the research and innovation product development and mass production (Kostyunina, 2012).

In Russia it is considered that the difference between science and technology parks is that the former are closer connected with research 
institutes and (or) universities in their activities (their creation is normally initiated by such entities), and the latter envisage, to a wide extent, an active integration of the efforts of not only research institutes, but also the research departments of big industrial groups (or concerns), small and medium-size enterprises and innovation companies. But, in general, such innovative infrastructure facilities are created with the single object of the science and technology development - formation and growth of the new knowledge-intensive companies using the R\&D findings.

That is why, as mentioned above, such concepts as science, research and technology parks are not divided in some sources based on the general principle of their activities the local agglomeration of the technological knowledge to create innovative manufacturing (Goldstein, 1990). However, in Russia parks are most often called 'technology parks' or 'science and technology parks', placing emphasis on their practical focus.

Thus, in a strict sense technology park means a territory with entities and favorable conditions for the location of technology intensive companies, research institutes and labs, the conduct of scientific research and development of technologies for commercialization of their results.

In an extended sense, technopark - is a system of the fastest growing relations between the entities located in its territory - research, business, educational and supporting.

However, in its statistical analysis of the status and main trends in the innovative infrastructure development, the International Association of Science Parks (IASP) uses a common term 'STP' (Science \& Technology Parks) (IASP, 2015).

Today about one half of all STPs in the world $(47.1 \%)$ do not have any clear specialization in the wide range of technologies (general science clusters). A bit more than one third of parks $(34.5 \%)$ have a clear specialization in one or more high-tech areas, but also provide their premises to some companies that are non-core for the park's specialization. About $20 \%$ of technoparks are focused on development of one or few types of technologies (specialized science clusters).

\section{Trends of science and technology park development in global context}

The modern trend of creating technology parks in the cities is obvious. According to the IASP, $94.1 \%$ of all science and technology parks are located in cities and towns, and only $5.9 \%$ - close to them. For 8 years, the number of STPs located other than in urban areas has dropped to $21.1 \%$ (in $2007,27 \%$ of science and technology parks were located close to cities). As for the size of the city to accommodate science and technology parks, small towns with up to 500,000 residents dominate, accounting for $45.4 \%$ of the facilities concerned. $35.3 \%$ is represented by the big cities with over 1 million residents (IASP, 2015).

Considering the territory where the technological cluster carries out its business, one may state that most of the world science and technology parks are located outside the university campuses $(65.5 \%)$. The rest of facilities (34.5\%) function in campuses, including $30.3 \%$ of all parks - in the campus, and $4.2 \%$ - outside the campus area.

One of the attributes of a state-of-the-art science or technology park is a compulsory availability of a business incubator or a research center in it. $91.6 \%$ of all STPs have a business incubator, and $80.7 \%$ - a research center, while only $21.8 \%$ of the concerned objects of innovative infrastructure have the areas to lease out to residents. 


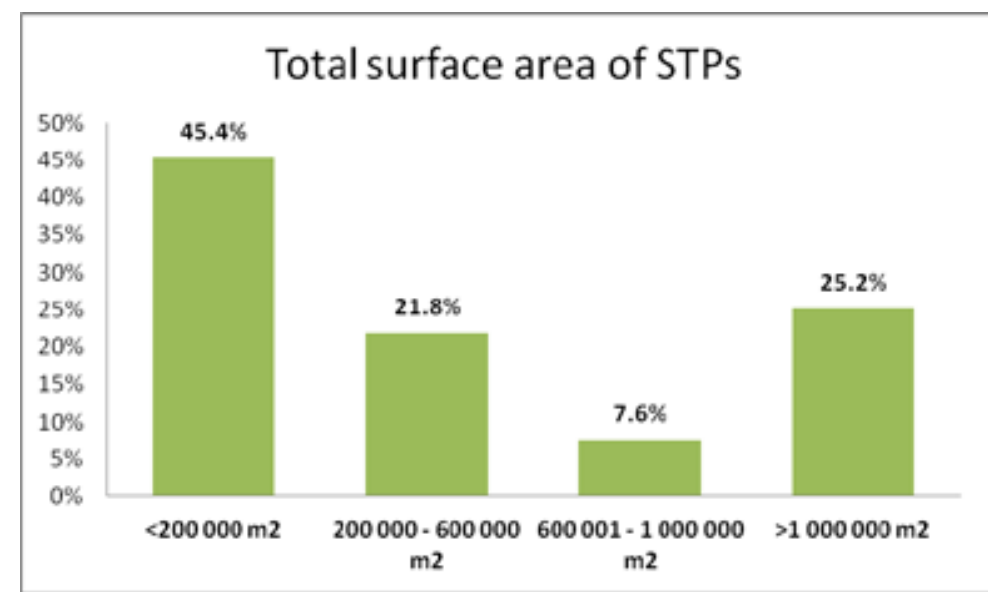

Fig 2. Size of Science and Technology Parks

Almost a half of all technoparks (45.4\%) have the area of up to 200,000 sq.m. and less than 100 STP-located entities (resident companies); only a quarter of such clusters have the area of over 1,000,000 sq.m. (25.2\%), and the share of STPs with over 1,000 resident companies is equal to $3 \%$. Thus, the trend towards creation of small technology or science parks can be traced, what could be explained by the efficiency of their functioning in just such format (IASP, 2015).

\section{Conclusion}

Today there are over 700 technology parks worldwide. The greatest number of the operative technology parks is registered in the United States which is $42 \%$ of the total number of the world innovation infrastructure facilities in question. $34 \%$ of technoparks are situated in EU countries and $11 \%$ - in China. The remaining $13 \%$ falls to the rest of the world (Kostyunina, 2012).

Thus, it may be concluded that so far a sufficient advanced foreign experience has been gained in creation and functioning of science, research and technological clusters. The case studies allow to identify the required criteria of the innovation infrastructure facilities location and the key factors of efficiency of their functioning. Also it is possible to determine the role of technoparks creation in setting up the innovation and industrial clusters, since one of the main objectives in creating such facilities is to promote industrial development and emergence of the new high-tech industries. In addition, technological clusters greatly encourage regional development and creation of new jobs.

Considering the successful practice of science and technology parks development, it may be concluded that the initial prerequisites for their efficient functioning are the creation of parks:

- in (or close to) the city with the developed research and educational basis (the highlyqualified scientific and research personnel);

- close to universities and (or) research institutes promoting the formation of the scientific community for research and development purposes, as well as the joint use of the generated results.

Also the rapid growth of the innovative infrastructure facilities is connected with the countries need to reorganize excessive, misused industrial enterprises and to reasonably use the vacant university premises. The creation (on their basis) of small and medium-size innovative 
high-tech companies through operation of the technology or science parks proved to be one of the most successful forms of the innovation activity arrangement. In many countries, the popularity of the technoparks creation is explained by the fact that innovative infrastructure development promotes more rational allocation of productive forces and breaking the socioeconomic disproportions between various city districts by decentralizing the industry and by transforming the least economically developed areas into the scientific and industrial centers with high living standards.

Thus, the technoparks structures development has become an essential part of the modern knowledge-intensive economies. The experience in creation of such innovative infrastructure facilities is of some special interest for Russia, as it concerns the need for reshaping the excess urban industrial areas located inside the urban territories. However, when creating the innovative infrastructure facilities, it is necessary to take into account all feasible constraints a technology or science park may face. The above-mentioned constraints may be: insufficiently efficient tools of venture capital financing, the problem of technologies commercialization, as well as the problem of innovation reproduction and development (establishment of just one successful business in a technology park), the lack of the required connection between a cluster and a university and (or) a research institute, the lack of qualified personnel, etc.

Another urgent issue related to the development of the technopark structures is the estimation of their economic efficiency, which can be the subject of further research.

\section{References}

Barinova, V., Kocjubinskij, V., Muhlisova, A. \& Rybalkin, V. Tehnoparki stran mira: organizacija dejatel'nosti i sravnenie [Technoparks in Different Countries: activity arrangement and comparison]. Moskow, Delo RANHiGS, 2012.

Bellini, N. \& Teras, J. (2012). Science and Technology Parks in the Age of Open Innovation. The Finnish Case, Emerging Issues in Management. Innovation Management in Global Markets, 1, 25-44.

Buades, F., Fey-Gosset, L. \& Nussbaum, N. Sophia Antipolis Territoire d'avenir, Home of the future, Audacia editions, Nice, 2009.

Collaton, E. \& Bartsch, C. (1996). Industrial Site Reuse and Urban Redevelopment, Cityscape. Urban Environmental Policy, 2(3), 6-17.

Correia, A.M. \& Gomes, M.L. (2014). Potentialities and limits for the local economic and innovative development: a comparative analysis of technology parks located in the Northeast region of Brazil. International Journal of Innovation and Learning, 15(3), 274-298.

Doutriaux, J. (1998). Canadian Science Parks, Universities, and Regional Development, Local and Regional Systems of Innovation. Local and Regional Systems of Innovation, 14, 303-324.

Economic and Social Commission for Asia and the Pacific. Strengthening technology incubation system for Creating high technology - based enterprises in Asia and the Pacific. United Nations Publication, 2001.

Goegl, H.-J. \& Schedler, C. Successful models of Cooperation between Universities and Companies in Europe, Landschaft des Wissens, 2009.

Goldberg, I. \& Goddard, J.G. Igniting Innovation. Rethinking the Role of Government in Emerging Europe and Central Asia. World Bank, 2011. 
Goldstein, H.A. \& Luger, M.I. (1990). Science/Technology Parks and Regional Development Theory. Economic Development, 4(1), 64-78.

Grunder- und Innovaionszentrum im TechnologiePark Koln. (2015). http://www.giz-koeln.de/, Accessed 10 September 2015.

International Association of Science Parks and Areas of Innovation. (2015). http://www.iasp.ws/ statistics, Accessed 15 September 2015.

Kocak, O. \& Can, O. (2013) Determinants of inter-firm networks among tenants of science technology parks. Industrial and Corporate Change, 23(2), 467-492.

Korolenko, A. (2011). Sravnenie mezhdunarodnogo i rossijskogo opyta reorganizacii proizvodstvennyh zon [Comparison of the International Practices of the Redevelopment of the Industrial Areas]. Regional'nye Issledovanija [Regional Studies], 4, 36-43.

Kostyunina, G. \& Baronov, V. (2012). Tehnoparki v zarubezhnoj i rossijskoj praktike [Technopars in foreign and Russian practice]. Vestnik MGIMO-University, 3, 91-99.

Lichtenberg, S. (1989). New project management principles for the conception stage: outline for a new 'generation'. International Journal of Project Management, 7 (1), 46-51.

Link, A. N., Scott, J.T. (2007). The economics of university research parks. Oxford Review of Economic Policy, 23(4), 661-674.

Liu, J., (2006). Experience and Enlightenment Cambridge Science Park - A Model of University Science Park. Journal of Cambridge Studies, 1(2).

McAndrews, R., The Birthplace of Silicon Valley: A History of Land Development at Stanford University. Sandstone \& Tile, 1995.

Murzina, E. (2014). Problemy i perspektivy vzaimodejstvija biznesa i vlasti v oblasti proektov $\mathrm{s}$ ispol'zovaniem gosudarstvenno-chastnogo partnerstva v Rossii [Problems ad Perspectives of Cooperation between Business and Government in Projects based on Public-Private Partnerships in Russia]. Ekonomika ustojchivogo razvitija [Economics of Sustainable Development], 3 (19), 168-177.

Murzina, E. (2015). Redevelopment promyshlennyh territorij kak sposob sozdanija innovacionnyh territorij [Redevelopment of the Industrial Areas as a Way of Creation of the Innovative Areas)]. Ekonomika ustojchivogo razvitija [Economics of Sustainable Development], 1 (21), 127-132.

Saff, G. (1993). Science Parks: A Critical Assessment. Journal of Planning Literature, 8, 107123.

Site Officiel de Sophia Antipolis. http://www.sophia-antipolis.org/, Accessed 17 September 2015.

Sung, T.K. (2002) Knowledge and Technology transfer in Technoparks Development. Int. J. Technologies, Policy and Management, 2(3), 240-259.

Tanev, S., Knudsen, M., Bisgaard, T. \& Thomsen, M. (2011). Innovation Policy Development and the Emergence of New Innovation Paradigms. Technology Innovation Management Review, November.

Tereshenko, L. \& Kalmykova, A. (2011). O pravovom statuse tehnoparkov [Concerning the Legal Status of the Technoparks]. Zhurnal rossijskogo prava [The Journal of Russian Law], 2011, 12, 21-30.

Wojewnik, A. \& Kowalski, R. (2015). Investing In Industrial-Technology Parks. City DevelopmentA Cost-Benefit Analysis, Real Estate Management and Valuation, 23(1), 24-41. 
Zielinski, M., Rogala, A. \& Takemura, M. (2014). Business Model of Science and Technology Parks: Comparison of European Best Practice. The Bulletin of the Faculty of Commerce Meiji University, 1, 15-28.

\title{
Международный опыт создания \\ объектов инновационной инфраструктуры \\ как механизм развития инновационной экономики \\ и повышения эффективности использования территорий
}

\author{
E.C. Мурзина \\ Национальный исследовательский университет \\ Высшая школа экономики \\ Россия, 101000, Москва, ул. Мясницккая, 20
}

\begin{abstract}
Статья подготовлена аспирантом 3-его года обучения НИУ «Высшая икола экономики» 6 рамках диссертационного исследования. В данной статье рассмотрены концептуальные основы создания и функционирования научных и технологических парков, являюшихся одними из ключевых объектов инновационной инфраструктуры. Посредством анализа мирового опыта реорганизации промышленных и университетских территорий выявлены основные модели формирования технопарковых структур, формы и характеристики современных научных и технологических парков, условия их эффективного функичонирования. Также автором обоснована необходимость учета международного опыта создания технопарков в рамках российской практики перепрофилирования избыточных промышленных зон, расположенных внутри городских территорий.

Ключевые слова: инновачионная инфраструктура, научные и технологические парки, реорганизация промышленных зон, модели создания технопарков, наукоемкое производство, резидент научного/технологического парка, специализация деятельности технопарков.
\end{abstract}

Научная специальность: 08.00.00 - экономические науки. 